\title{
Sprawozdanie z konferencji naukowej pt. Polskość jedna czy trzy? Echa zaborów u progu odzyskania niepodległości oraz wspótcześnie, Poznań, 29-30 XI 2018 r.
}

W roku 2018 r. minęło 100 lat od momentu, kiedy państwo polskie, po 123 latach zaborów, odzyskało niepodległość. Przez blisko półtora wieku trzej zaborcy zarządzali terenami byłej I Rzeczypospolitej według własnych, odrębnych wzorców - różniąc się językiem, kulturą, porządkiem prawnym, aparatem administracji, systemem oświaty czy walutą. Wydarzenia roku 1918 przyniosły kres ich panowania, kładąc jednocześnie podwaliny pod nową, jednoczącą się Polskę. Rocznica ta stała się inspiracją do zorganizowania wielu konferencji, sympozjów, debat.

W cykl tych licznych inicjatyw wpisała się także dwudniowa ogólnopolska studencko-doktorancka konferencja naukowa pt. Polskość jedna czy trzy? Echa zaborów u progu odzyskania niepodległości oraz współcześnie zorganizowana przez Sekcję Myśli i Kultury Politycznej Studenckiego Koła Naukowego Historyków im. Gerarda Labudy. Punktem wyjścia była konstatacja, że echa zaborów da się słyszeć po dziś dzień, ponieważ 12 dekad obcego panowania ze szczególną mocą odcisnęło się nie tylko w świadomości pokoleń pamiętających zabory, ale też tych, wychowanych już w wolnej Polsce. Organizatorzy konferencji postawili takie pytania jak: w jaki sposób porozbiorowa myśl polityczna odnosiła się do problematyki odzyskania niepodległości? Czy w Wielkopolsce rozumiano i definiowano polskość tak samo, jak w Królestwie Polskim bądź w Galicji? W jaki sposób zabory zdeterminowały podejście do partycypacji w życiu publicznym czy takich kwestii, jak: edukacja, język, literatura? Konferencja była zatem próbą dokonania swoistej introspekcji - szukania odpowiedzi na pytania dotyczące wpływu zaborów na procesy kształtowania się niepodległego państwa, a także na ich dziedzictwo we współczesnej Polsce. 
Omawiana konferencja była jedną z naukowych inicjatyw towarzyszących poznańskiej rocznicy odzyskana niepodległości. Program wydarzenia składał się z czterech paneli dyskusyjnych odbywających się w murach Collegium Historicum Uniwersytetu im. Adama Mickiewicza i dwóch debat eksperckich goszczonych przez Poznańskie Towarzystwo Przyjaciół Nauk.

Wykład otwierający wydarzenie wygłosił prof. Przemysław Matusik (IHUAM), zaś jego tematem przewodnim była refleksja na temat narodzin poczucia polskości w XIX w. Referent przewrotnie zakwestionował tytuł konferencji i zasugerował istnienie zaledwie dwóch "polskości", powołując się na słowa Ottona von Bismarcka. Premier Prus twierdzil, że tożsamość narodowa Polaków nie jest czymś naturalnym, lecz sztucznie wykreowanym przez patriotycznych szlacheckich agitatorów. W związku z tym niższe i mniej świadome warstwy mieszkańców Wielkopolski można z łatwością przekształcić równie dobrze w Niemców. Dalsza część wykładu systematycznie obalała te kontrowersyjne tezy. Za przykład posłużył stosunek polskiego chłopstwa do języka i kultury w okresie germanizacji. Oddolna edukacja oparta na krzewieniu języka polskiego przedstawiona została jako uniwersalne spoiwo, stanowiące punkt wyjścia dla silnej, wspólnej tożsamości narodowej w walce z opresją systemów zaborczych. Jednym z ważnych aspektów zasygnalizowanych przez prof. Matusika był fakt, że różnice w polskości mogą być inne tylko terytorialne, ale również klasowe.

Pierwszy panel dyskusyjny poświęcony został w głównej mierze tematyce politycznej i religijnej. Otworzył go referat Michała Gęsiarza: Niepodległość, ale jaka? Wizje walki o wyzwolenie wedtug polskich socjalistów przed Rewolucja 1905, który dotyczył debaty niepodległościowej stoczonej przez Polską Partię Socjalistyczną i Socjaldemokrację Królestwa Polskiego i Litwy w okresie poprzedzającym Rewolucję 1905 r. w Królestwie Polskim. Autor skupił się na przedstawieniu kluczowych argumentów obu stron wyrażonych w pismach Róży Luksemburg i Kazimierza Kelles-Krauza, podejmując próbę przeniesienia się w głąb świadomości politycznej schyłku XIX w., kiedy niepodległa Polska była jeszcze koncepcją nieoczywistą i pozornie odległą. Drugi z referatów został wygłoszony przez Macieja Skrzypka, dotyczył losów polskiej chadecji do okresu międzywojennego (Formowanie się partii chrześcijańskiej demokracji u progu niepodległości). Autor rozważył genezę ruchu, jego ewolucję u progu niepodległości i źródła utraty politycznego znaczenia w latach dwudziestych.

W dalszej części obrad zostały poruszone kwestie religijne, zainicjowane wystąpieniem Jędrzeja Jakubowskiego pt. Związki wyznaniowe w zaborze rosyjskim i ich 
wpływ na tożsamość narodowa. Tematem przewodnim była tym razem polityka kościelna władz w zaborze rosyjskim, ze szczególnym wskazaniem na instrumentalne wykorzystywanie kwestii religijnych w polityce zwalczania przejawów polskości. Panel zwieńczony został referatem pt. Wina moja czy sasiada - czy wśród wspótczesnych Polaków przetrwaly poglądy XIX-wiecznych rodaków? autorstwa Łukasza Lomperta. Opierając się na pilotażowych badaniach terenowych przedstawił on swoje wnioski na temat podobieństw i różnic świadomości historycznej mieszkańców ziem trzech dawnych zaborów. Mimo ograniczonego zakresu dostępnych na tym etapie badań, referat rzucił światło na różnice edukacyjne i tożsamościowe pomiędzy polskimi województwami. Panel zamknęła dyskusja, która została zdominowana refleksjami na temat relacji między poszczególnymi wyznaniami na terenie carskiej Rosji.

W drugiej części obrad tematyka wkroczyła w sfery prawne i literaturoznawcze. Pierwszy referent, Łukasz Piosik, swoją uwagę poświęcił tematyce pornografii w prawodawstwie trzech zaborców („Kto publicznie dobre obyczaje kazi...” Kilka uwag o tabuizacji zjawiska pornografii w tekstach prawnych okresu zaborów). Zastosowana metodologia filozofii języka pozwoliła uchwycić zmiany semantyczne w określaniu tego tabuizowanego w przestrzeni publicznej zjawiska. Obyczajowości, ale skupionej na tematyce rozwodów i anulowania małżeństw, poświęciła swoje wystąpienie również Sara Kusz („Turystyka rozwodowa” $i$ „dziewice konsystorskie” albo publicysta o problemach prawa matżeńskiego osobowego II Rzeczypospolitej). Wychodząc od publicystyki Boya Żeleńskiego, autorka przedstawiła pęknięcia w strukturze pozaborczego prawa cywilnego, które umożliwiały legalne drogi starania się o rozwód u progu II Rzeczypospolitej. W każdej z dzielnic obowiązywały inne, a nawet sprzeczne przepisy, co spowodowało masowe przeprowadzki lub konwersje wyznaniowe wśród rozwodników.

Historii architektury poświęcone zostało wystąpienie Poznań-Kraków-Warszawa, trzy formy architektoniczne polskich miast Stanisława Knapowskiego. Autor przeanalizował wpływ stolic mocarstw zaborczych na Poznań, Kraków i Warszawę, zarówno piętno nacechowanych ideologicznie budynków publicznych, jak i podobieństwa zwykłych kamienic. Pierwsze dwa miasta okazały się wciąż złączone szeregiem analogii z Berlinem i Wiedniem, natomiast relacja Warszawa - Petersburg wydała się bardziej skomplikowana. Aspekt literaturoznawczy w postaci problematyki kreacji mitu Galicji w literaturze został wniesiony do dyskusji przez Jolantę Jasielec („Cesarz, na szczęście, wszystkich tych świństw nie slyszat i nadal patrzyt równie pogodnie”. Obraz Galicji we wspótczesnym kryminale retro na podstawie powieści Maryli Szymiczkowej). Nostalgia za austriackim zaborem została przedstawiona z perspektywy literatury popularnej, ale również wydarzeń kulturowych i marketingu. Odsłonięto 
pewien rodzaj przywiązania do galicyjskiej tożsamości, różniący się swoim stopniem w zależności od regionu i specyfiki danej społeczności.

Pierwszy dzień obrad zakończył się referatem „W istocie brzmi nam złoty róg...” Teatr Polski w Poznaniu na tle wydarzeń społeczno-politycznych 1918 roku autorstwa Agnieszki Zawiszy. Przedstawiona została historia poznańskiego Teatru Polskiego począwszy od budowy do kulminacyjnego okresu w grudniu 1918 r., kiedy to w tygodniach poprzedzających powstanie istotną rolę kreowania tożsamości pełniło przedstawienie Wesela Stanisława Wyspiańskiego. Spektakl zbiegł się w czasie z obradami Sejmu Dzielnicowego i stanowił preludium dla jednego z nielicznych wygranych powstań w dziejach Polski.

Wieczorem uczestnicy wydarzenia przenieśli się do sali obrad PTPN, gdzie w pierwszej debacie eksperckiej wzięli udział profesorowie Piotr Śliwiński, Waldemar Łazuga oraz Violetta Julkowska. Moderatorem debaty, zatytułowanej Echa zaborów: Mit / historia / idea, był dr Mariusz Menz z Zakładu Myśli i Kultury Politycznej UAM. Debata została zdominowana przez intelektualne rozważania na temat istoty polskiej tożsamości narodowej, a centralnym wątkiem było miejsce Wielkopolski $\mathrm{w}$ narodowym imaginarium. Towarzysząca debacie dyskusja przeciągnęła się do późnych godzin wieczornych, a wśród poruszanych tematów znalazło się miejsce m.in. dla, wcale nie centralnego, wizerunku Wielkopolski w innych częściach kraju.

Obrady drugiego dnia konferencji rozpoczęto w ramach panelu dotyczącego tematyki prawniczej. Pierwsze dwa referaty poświęcone zostały różnicom w prawach zaborczych i procesom unifikacji prawa po roku 1918. Patryk Maćkowiak skupił się na procesie tworzenia jednolitego prawa cywilnego (Gmach nowy od fundamentów. Wokót unifikacji prawa cywilnego w Polsce po I wojnie światowej), zaś Daniel Mielnik w referacie zatytułowanym Prawodawstwo karne w okresie zaborów ze szczególnym uwzględnieniem kary śmierci zarysował podobieństwa i różnice w zaborczej legislacji dotyczącej kary śmierci i ich wpływ na późniejsze polskie zapisy. Prawo cywilne powróciło w wystąpieniu Izabeli Janickiej: Różnice prawa matżeńskiego w zaborach. Ponownie na mównicy pojawił się wątek ślubów i rozwodów, które w systemie prawnym II Rzeczypospolitej rozregulowane były niespójną spuścizną zaborów. Przedostatnie wystąpienie, Spuścizny prawne zaborców na przykładzie pruskiego urzędu stanu cywilnego, należało do Patrycji Krawczyk, która przybliżyła uczestnikom konferencji metodykę pracy nad dokumentacją zaborczych Urzędów Stanu Cywilnego.

Ostatni panel konferencji miał charakter interdyscyplinarny. Jako pierwsza pojawiła się kwestia militarna, wprowadzona do dyskusji przez Dawida Gralika: Rola spuścizny armii zaborczych $w$ procesie formowania Wojska Polskiego, który przybliżył 
kwestię spuścizny państw zaborczych z perspektywy tworzenia struktur militarnych II Rzeczypospolitej. Tematyka referatu skupiła się wokół wyzwań zjednoczenia żołnierzy wywodzących się z różnych szkół wojskowych, stosunków etnicznych w armii młodej republiki oraz procesu tworzenia polskojęzycznego nazewnictwa wojskowego. Autorka kolejnego wystąpienia, Martyna Glock, na bazie ankiet przeprowadzonych wśród uczniów liceów w Poznaniu i Kielcach omówiła stosunek uczniów szkół wyższych do patriotyzmu lokalnego oraz ich związek z rodzinnymi stronami (Licealiści o swoim regionie- pola skojarzeniowe o osobistościach lokalnych na podstawie badań licealistów $z$ Kielc i z Poznania). Przebadana została również rozpoznawalność ważnych postaci związanych $\mathrm{z}$ regionem, w której istotnym aspektem były relacje między rozpoznawalnością postaci historycznych i współczesnych celebrytów. Panelową część konferencji zamknął referat zatytułowany Edukacja w zaborze pruskim ze szczególnym uwzględnieniem problematyki przymusowej germanizacji dzieci oraz polskich bibliotek ludowych autorstwa Oliwiera Grzywaczewskiego. Wystąpienie poświęcono praktykom germanizacyjnym w polskich szkołach oraz problemom, jakie władza stwarzała polskim bibliotekom w zaborze pruskim. Pozwoliło to niejako spiąć klamrą całą część panelową, jako że tematyka powróciła zarówno do wykładu wprowadzającego, jak i politycznych aspektów pierwszego referatu.

Wydarzenie zostało zakończone drugą z debat eksperckich. W panelu Echa zaborów: pamięć / tożsamość / materia udział wzięła kolejna trójka poznańskiej kadry profesorskiej Krzysztof Podemski, Jacek Schmidt i Hanna Grzeszczuk-Brendel. Zgodnie z zaplanowaną tematyką, panel był skupiony na bardziej materialnych aspektach polskości, a debatujący poświęcili swoją uwagę polskości przejawiajacej się $\mathrm{w}$ architekturze, wyznaniach, życiu codziennym i poglądach politycznych. Po przeniesieniu tych danych na mapę uczestnicy mogli, niepokojąco często, dostrzec niezatartą granicę trzech zaborów. Pokłosiem zorganizowanej konferencji ma być również monografia.

Stanisław Knapowski

Uniwersytet im. Adama Mickiewicza w Poznaniu

ul. Uniwersytetu Poznańskiego 7

61-614 Poznań 
Magdalena Patrzałek

Uniwersytet im. Adama Mickiewicza w Poznaniu

ul. Uniwersytetu Poznańskiego 7

61-614 Poznań

Michał Gęsiarz

Uniwersytet im. Adama Mickiewicza w Poznaniu

ul. Uniwersytetu Poznańskiego 7

61-614 Poznań 